DOI https://doi.org/10.30525/978-9934-588-90-7-10

\title{
МОДАЛЬНІ ПАРАМЕТРИ ПИТАЛЬНИХ ВИСЛОВЛЕНЬ
}

\author{
Педченко С. О. \\ кандидат філологічних наук, \\ доиент кафедри украӥнської мови \\ Полтавський національний педагогічний університет \\ імені В. Г. Короленка \\ м. Полтава, Украӥна
}

Актуальним аспектом сучасної теорії мовної модальності є специфіка реалізації субкатегорійних модальних значень у питальних реченнях. Ця проблема, зі свого боку, вимагає розв'язання таких важливих теоретикопрактичних викликів, як окреслення статусу категорії «питальна модальність», характеристика засобів іiї репрезентації, з'ясування лінгвопрагматичних параметрів тощо. У мовознавстві до цього часу не вироблено єдиного погляду на означене лінгвальне явище. Прихильники широкого тлумачення модальності розглядають питальність як одне 3 основних модальних значень $[9 ; 10]$. За їхнім переконанням, об'єктивна модальність функціює на основі протиставлення розповідного, спонукального й питального компонентів. Інші вчені наполягають на недоцільності введення до кола модальних значень категорій комунікативної установки мовлення, пропонуючи обмежитись семами реальності / ірреальності (можливості, необхідності та бажальності) [5]. Фактичний матеріал, що є в нашому розпорядженні, потверджує невиправданість ототожнення категорій модальності й настанови, оскільки вони належать до різних рівнів речення - семантичного й комунікативного. Так, семантико-синтаксична структура питального за метою висловлювання речення може бути репрезентована різними типами модальності: Луги, луги, пропахлі сіном прілим, чи ви мене впізнали, земляка? (В. Симоненко) - ірреальне об'єктивно-модальне значення; Мамусю, а для чого ие все? (О. Забужко) - реальне об'єктивно-модальне значення; Хіба йому, такому перемерзлому, такому перетрудженому на своєму віку, зігрітися лише травою чи землею? (М. Матіос) - епістемічне суб'єктивно-модальне значення; Чи не можна мені відпочити? (3. Тулуб) - волітивне суб'єктивно-модальне значення.

Як бачимо, основними маркерами модальних значень у цих реченнєвих конструкціях $€$ питальні частки, окреслити функційносемантичні межі яких неможливо без залучення результатів дослідження семантико-синтаксичних властивостей питальних висловлень. Більшість учених 3-поміж характерних особливостей цих структур як основну 44 
виокремлюють здатність маніфестувати волюнтативне модальне значення - спонукати адресата до повідомлення потрібної мовцю інформації [4, с. 145; 6, с. 21; 7, с. 129]. Питальний комунікативний акт, мотивований усвідомленою продуцентом необхідністю розв'язати проблему вибору між альтернативними рішеннями [8, с. 206], покликаний «спровокувати» в процесі мовленнєвої поведінки бажану відповідь реципієнта [2, с. 315-316]. Модальні значення питального висловлення детерміновані наявністю / відсутністю пресупозитивних знань мовця. Якщо суб'єкт мовлення хоче поповнити інформацію про події, явища, об’єкти тощо, якою володіє, з'ясувавши нові деталі, модальне наповнення речення визначають як реальне: Як же все починалося? (М. Савченко); ...які двигуни потрібні для твоєї машини? (С. Жадан); Де могили наших героїв, товаришів наших? (О. Довженко). Л. Кадомцева кваліфікує такі структури як «речення прямої з'ясувальної питальності» [7, с. 132], Ш. Баллі, ранжувавши дескриптивний компонент висловлення (пропозицію) на дві частини - диктум і модус, трактує їх як «часткові диктальні» (на зразок Хто виконав завдання?) та «часткові модальні» (на зразок Чи це завдання він виконав?), І. Вихованець дефінує означені конструкції як частковопитальні [4, с. 146]. Почасти інтонаційносинтаксичні засоби стають оформлювачами реченнєвих структур, спрямованих на з'ясування істинності чи хибності пропозиційного змісту попередніх висловлень: Ти знаєш його? (А. Тесленко); Чи образив його xmocb? (Остап Вишня). Модальність таких висловлень визначається як ірреальна, здебільшого ускладнена епістемічними, волітивними, аксіологічними суб'єктивно-модальними значеннями: - Чи думала ти про те, щчо чорна курочка з білими цяяточками - символ нічного неба?! (I. Роздобудько); А хіба можна без людей, дочко? - здивувалася мати (Є. Гуцало); Невже йому нецікаво їхати без мене? (Ю. Андрухович); Так ти щцо, i ночував в степy? (М. Вінграновський). Цей тип конструкцій загалом відповідає «реченням прямої уточнюючої питальності», у термінології Л. Кадомцевої, що «розраховані на перевірку знань, коли мовець майже передбачає зміст очікуваної відповіді» [7, с. 131-132], «повним модальним» і «повним диктальним» («модально-диктальним») питанням Ш. Баллі [1] та «загальнопитальним», за класифікацією I. Вихованця [4, с. 146], реченням. Складність модальної параметризації розгляданих висловлень потверджує й те, що прихильники когнітивної теорії модальності ідентифікують питальні речення як такі, що «демонструють доцентрово-відцентровий тип модальності», адже «будьяке запитання містить у собі певне відображення дійсності і спонукання до заповнення деяких лакун знання» [3, с. 83].

Отже, пропозитивний зміст питальної конструкції може бути модифікований різноманітними суб'єктивно-модальними відтінками. Партикули при цьому автономно не реалізують ту або ту прагматично 
орієнтовану семантику, а формують модальний план висловлення сукупно з іншими лінгвальними та паралінгвальними засобами (просодичними, лексико-граматичними, синтаксичними тощо).

\title{
Література:
}

1. Балли Ш. Общая лингвистика и вопросы французского языка. М. : Издательство иностранной литературы, 1955. 416 с.

2. Бенвенист Э. Общая лингвистика. М. : Прогресс, 1974. 446 с.

3. Бріцин В. М. Модальність і предикативність: лінії розмежування і протиставлення. Мовознавство. 2015. № 2. С. 77-85.

4. Вихованець I. Р.Граматика української мови. Синтаксис. К. : Либідь, 1993. 368 с.

5. Доценко О. Л. Семантико-прагматичний синтаксис : особливості вираження модальності. К. : Міленіум, 2006. 226 с.

6. Каранська М.У. Синтаксис сучасної української літературної мови. К. : НМКВО, 1992. 399 с.

7. Сучасна українська літературна мова : Синтаксис / [за заг. ред. І.К. Білодіда]. К. : Наукова думка, 1972. 515 с.

8. Теньер Л. Основы структурного синтаксиса. М. : Прогресс, 1988. $656 \mathrm{c}$.

9. Ткачук В. М. Категорія суб'єктивної модальності. Тернопіль : Підручники й посібники, 2003. 240 с.

10. Шинкарук В. Д. Модус і диктум у структурі речення : дис. ... Д-ра філол. наук : 10.02.01. Чернівці, 2003. 465 с.

DOI https://doi.org/10.30525/978-9934-588-90-7-11

\section{СЕМАНТИКА СУБ'ЄКТА ЯК ГОЛОВНИЙ ЧИННИК КОНСТРУЮВАННЯ СИНТАКСИЧНОЇ СТРУКТУРИ}

\author{
Сулима О. П. \\ кандидат філологічних наук, \\ дочент кафедри української мови
}

Національний педагогічний університет імені М. П. Драгоманова м. Київ, Украӥна

У середині XX ст. у світовому та українському мовознавстві популярною стала вербоцентристська теорія, згідно з якою компоненти структури речення поділяються на облігаторні, передбачені валентністю предиката, - та сирконстанти, необов'язкові. У $80-\mathrm{x}$ pp. ХХ ст. 